\title{
Professional Development Of An Educational Psychologist In The System Of Psychological And Counseling Service Of The University
}

\section{Desarrollo profesional de un psicólogo educativo en el sistema de servicio de psicología y consejería de la universidad}

\author{
Yulia Anatoliyevna Repkina \\ The Institute of Social and Humanitarian Technologies of K.G. Razumovsky Moscow State \\ University of Technologies and Management (the First Cossack University), Moscow, Russia \\ ORCID: https://orcid.org/0000-0002-1852-3809 \\ Dmitry Vladimirovich Lukashenko \\ Research Institute of the Federal Penitentiary Service of the Russian Federation, Moscow, \\ Russia \\ ORCID: https://orcid.org/0000-0002-0045-6062 \\ Violeta Evgenievna Nikolashkina \\ Kutafin Moscow state law University (MSLU), Moscow, Russia \\ ORCID: https://orcid.org/0000-0001-8365-6088

\section{Liudmila Alekseevna Egorova} \\ Peoples' Friendship University of Russia (RUDN University), Moscow, Russia \\ ORCID: https://orcid.org/0000-0002-5159-1512 \\ Marina Georgiyevna Sergeeva \\ Research Institute of the Federal Penitentiary Service of Russia, Moscow, Russia \\ ORCID: https://orcid.org/0000-0001-8365-6088
}

Received 09-08-20 Revised 10-10-20

*Correspondencia

Email: rja-75@ rambler.ru
Accepted 20-12-21 On line 02-09-21
Citar como:
Anatoliyevna, Y., Vladimirovich, D., Evgenievna, V., Alekseevna, L., \& Georgiyevna, M. (2021). Professional Development Of An Educational Psychologist In The System Of Psychological And Counseling Service Of The University. Propósitos y Representaciones, 9(SPE2), e986. Doi: http://dx.doi.org/10.20511/pyr2021.v9nSPE2.986 


\section{Summary}

The priority goal of modernizing the Russian education system is to ensure a high quality of knowledge. The psychological and counseling service is capable of implementing many qualitative changes in the higher education system. The development of the psychological and counseling service is due to its role in the modernization of Russian education, on the one hand, and the growing need for educational psychologists, on the other. The outflow of psychologists from the education system negatively affects the quality of the services and the image of the psychological and counseling service in education and society as a whole. Consequently, the career and personal development of a psychologist in the educational organization of higher education requires special research. The psychological support for an entry-level psychologist is necessary during the period of his/her professional development. The peculiarities of the psychological and counseling service require that a psychologist independently identify the directions and priorities of professional activity and show initiative in organizing the work and assessing its effectiveness. This, as a rule, is difficult for an entry-level educational psychologist. Certain difficulties for an entry-level psychologist are associated with the specifics of professional psychological and counseling activity. The tools of the professional activity of a trained psychologist are the personal and professional qualities, skills and abilities. Therefore, specific requirements are imposed on the personal and professional qualities of a psychologist. At the same time, in the professional environment, there are no unified standards for the personality of a psychologist and criteria for assessing the degree of his/her professionalism. Despite the constant updating of research in the field of psychological support for education, the identification of the necessary conditions for the training of a high-level specialist, the contradiction between the demand of modern society for a well-trained specialist and the insufficient level of readiness of young specialists for productive professional activity is deepening. An educational psychologist beginning to work at a university turns out to be unable to interact in a professional environment and experiences difficulties in establishing contacts with students and their parents.

Keywords: educational psychologist, professional career, educational environment, professional development, psychological and counseling service, higher education.

\section{Resumen}

El objetivo prioritario de la modernización del sistema educativo ruso es garantizar una alta calidad de los conocimientos. El servicio de psicología y asesoramiento es capaz de implementar muchos cambios cualitativos en el sistema de educación superior. El desarrollo del servicio psicológico y de asesoramiento se debe a su papel en la modernización de la educación rusa, por un lado, y a la creciente necesidad de psicólogos educativos, por otro. La salida de psicólogos del sistema educativo afecta negativamente la calidad de los servicios y la imagen del servicio psicológico y de asesoramiento en la educación y la sociedad en su conjunto. En consecuencia, la carrera y el desarrollo personal de un psicólogo en la organización educativa de la educación superior requiere una investigación especial. El apoyo psicológico de un psicólogo principiante es necesario durante el período de su desarrollo profesional. Las peculiaridades del servicio psicológico y de asesoramiento requieren que un psicólogo identifique de forma independiente las direcciones y prioridades de la actividad profesional y muestre iniciativa en la organización del trabajo y la evaluación de su eficacia. Esto, por regla general, es difícil para un psicólogo educativo principiante. Ciertas dificultades para un psicólogo principiante están asociadas con los aspectos específicos de la actividad psicológica y de asesoramiento profesional. Las herramientas de la actividad profesional de un psicólogo capacitado son las cualidades, habilidades y habilidades personales y profesionales. Por tanto, se imponen requisitos específicos a las cualidades personales y profesionales de un psicólogo. Al mismo tiempo, en el ámbito profesional, no existen estándares unificados para la personalidad de un psicólogo y criterios para evaluar el grado de su profesionalidad. A pesar de la actualización constante de la investigación en el campo del apoyo psicológico a la educación, la identificación de las condiciones necesarias para la formación de un especialista de alto nivel, la contradicción entre la demanda de la sociedad moderna de un especialista bien formado y el nivel insuficiente 
de se profundiza la preparación de los jóvenes especialistas para la actividad profesional productiva. Un psicólogo educativo que comienza a trabajar en una universidad resulta ser incapaz de interactuar en un entorno profesional y experimenta dificultades para establecer contactos con los estudiantes y sus padres.

Palabras clave: psicólogo educativo, carrera profesional, entorno educativo, desarrollo profesional, servicio psicológico y de orientación, educación superior.

\section{Introducción}

The need for effective training of future educational psychologists is dictated by the requirements of modern Russian society. Dynamic socio-economic processes have led to an increase in negative social phenomena: an increase in crime, unemployment, drug addiction, insufficient attention to the process of educating a healthy, highly moral and stress-resistant citizen.

The professional standard of a teacher sets high requirements for professional competencies. This requires raising the teacher's qualifications, but not only in the traditional building up professional knowledge, skills and abilities, but expanding the teacher's professional space as an indicator of his/her professional competencies.

Professional development is manifested in the teacher's ability to reflect on the professional level, strive to improve professional competencies, self-education, as well as discover, set and solve new pedagogical challenges of different levels - strategic, tactical, operational (Blinov, 2019).

In any case, new professional functions and tasks should be mastered in a timely manner, in full and constantly. Otherwise, a crisis of competencies occurs (dissonance in the use of traditional models of professional behavior in the changed conditions). In addition to advanced training, a teacher needs a specially organized scientific and methodological support, which makes it possible to switch from a passive model of adaptive behavior to an active model of professional development in the changed conditions of activity.

The methodological support of teachers, organization of self-education and professional self-development is not sufficiently provided with scientifically grounded recommendations that can contribute to the professional growth and professional success of each teacher (Dolzhich, Dmitrichenkova, 2018).

Analyzing the features of managing the professional development of teachers, it should be noted that in this process, some specific methods inherent only to the education system are traditionally strong: periodic refresher courses, a mentoring and coaching system, professional learning communities, the formation of a personnel reserve for filling managerial positions.

\section{Literature review}

In our opinion, the approaches to the training of educational psychologists require revision and enhancement of efficiency. In particular, we believe that in modern social realities, an educational psychologist should be trained as a specialist in "helping" professions, whose purpose is to provide professional, competent, social and psychological assistance to children and adolescents with normal mental development, as well as those with health and learning disabilities in educational institutions.

Helping professions are all those professions, where theories, research and practice focus on helping others, identifying and solving their problems and expanding knowledge 
regarding further human capabilities. These professions include healthcare (in a broad sense), psychiatry, clinical psychology, and various specialized fields such as educational and developmental psychology, social work, speech and hearing therapy, inclusive teaching, special education, etc (Isaeva, 2002).

Analysis of psychological and pedagogical research (Neverkovich et al., 2018; Volkova, Panchenko, 2018; Gurevich, 2019; Romanova, 1992; Ovcharova, 2003) has shown that this issue has always been relevant for the theoretical and practical educators. For example, the outstanding Russian psychologist L.S. Vygotsky considered it in the concept of the determination of the mental development of an abnormal child. This concept was contrasted with the biologic concept commonly agreed at that time, which asserts that the development of an abnormal child proceeds according to special laws. Justifying the provisions of the common laws of development (for handicapped children and their non-handicapped peers), L.S. Vygotsky emphasized that the social conditioning of mental development is common to both options. In all his works, the scientist noted that social, in particular pedagogical, influence is an inexhaustible source of the formation of higher mental functions, higher psychological functions, both in norm and in pathology (Abramova, 1994).

The main functions of psychological and counseling service in education, identified by the Russian researchers (Wang et al., 2018; Gorev et al., 2018; Burina, 2015; Bermus, 2020; Patrusheva, 2019; Zeer, 2003), are reflected in Table 1.

(Table 1): The main functions of psychological and counseling service in education

\begin{tabular}{|c|c|}
\hline Researchers & The main directions of psychological and counseling service in \\
\hline I.V. Dubrovina & $\begin{array}{c}\text { Psychological education, psychological prevention, psycho- } \\
\text { diagnostics, psycho-correction, developmental work, psychological } \\
\text { counseling. }\end{array}$ \\
\hline L.M. Friedman & $\begin{array}{l}\text { Organization of admission of children to school and completing } \\
\text { student groups; establishing friendly partnerships between teachers and } \\
\text { parents; studying the process of personal development of students; } \\
\text { psychological assessment of students; work of a school psychologist } \\
\text { with teaching and administrative staff. }\end{array}$ \\
\hline V.V. Rubtsov & $\begin{array}{c}\text { Diagnostics, correctional work, developmental classes, counseling, } \\
\text { psychological education, psychological prevention, scientific and } \\
\text { methodological work. }\end{array}$ \\
\hline H.T. Sheryazdanova & $\begin{array}{l}\text { Psycho-diagnostic and psycho-correctional work, developmental work, } \\
\text { individual work with children and consultations for parents and } \\
\text { teaching staff, the work of a psychologist as an expert. }\end{array}$ \\
\hline $\begin{array}{l}\text { I.A. Abeuova, } \\
\text { M.N. Makhamanova, } \\
\text { H.T. Sheryazdanova }\end{array}$ & $\begin{array}{l}\text { Psycho-diagnostics, psycho-correction, psychological counseling, } \\
\text { psychological prevention, psychological education, facilitation. }\end{array}$ \\
\hline R.T. Mendalieva & $\begin{array}{l}\text { Psychological and pedagogical diagnostics, psycho-correctional work, } \\
\text { psycho-prophylactic work, psychological education of teachers and } \\
\text { psychological training of students, improving the quality of the } \\
\text { educational process (systematic psychological analysis of the lessons), } \\
\text { facilitation. }\end{array}$ \\
\hline
\end{tabular}




\begin{tabular}{c|c}
$\begin{array}{c}\text { Z.M. Balgimbaeva, } \\
\text { N.S. Akhtaeva }\end{array}$ & $\begin{array}{c}\text { Organizational and psychological work, developmental and psycho- } \\
\text { assisted work, psycho-preventive work, psycho-diagnostic and psycho- } \\
\text { corrective work. }\end{array}$
\end{tabular}

Analysis of numerous sources on the problem of the professional activity of psychologists in the framework of the psychological and counseling service (Bírová et al., 2018; Sharonova, Trubnikova, Sokolova, 2018; Sergeeva et al., 2018; Blinova, Dugina, Zabolotskikh, 2018), showed that the psychological and counseling service in education has a unified vertical structure in the educational space of the country, including psychological services of educational institutions, city, district, regional centers of psychological and counseling services subordinate to the Ministry of Education and Science. The psychological and counseling service of any educational institution includes three main areas: research, applied and practical.

Based on the foregoing, we define an educational psychologist as a specialist in two dimensions: a teacher-psychologist and a specialist in helping professions. Therefore, we propose the following notion of an educational psychologist (Utemov et al., 2018):

The psychologist should have integral professional and personal qualities, civic engagement and the willingness and ability to fulfill professional duties, based on corresponding competencies. As the components of professional training of an educational psychologist, we distinguish special training, communicative skills training, individual and personal training

\section{Proposed methodology}

The structural-functional model of the continuing professional development (the CPD Management Model) of educational psychologists is systematized from the standpoint of the process approach with division into management levels.

The most detailed process approach to the modeling of CPD management of educational psychologists is given in Table 2.

(Table 2): Process approach in the modeling of CPD management of educational psychologists

\begin{tabular}{|c|c|c|}
\hline Processes & Problems & Solutions \\
\hline Management & \multirow{2}{*}{$\begin{array}{l}\text { Insufficient information about } \\
\text { the problems, difficulties in the } \\
\text { work of teachers } \rightarrow \text { the need } \\
\text { and demand for the service of } \\
\text { advanced training is not fully } \\
\text { determined. }\end{array}$} & Sending to advanced training courses. \\
\hline \multirow[t]{3}{*}{ Marketing } & & $\begin{array}{l}\text { Analysis of the professionalism of teachers } \\
\text { based on identifying their needs, studying the } \\
\text { learning outcomes. }\end{array}$ \\
\hline & $\begin{array}{c}\text { The providers of CPD services } \\
\text { (opportunities) have not been } \\
\text { determined. }\end{array}$ & $\begin{array}{c}\text { Based on the identified needs, find } \\
\text { opportunities for CPD; } \\
\text { Involvement of teachers in various forms of } \\
\text { CPD; } \\
\text { Selection }\end{array}$ \\
\hline & $\begin{array}{c}\begin{array}{c}\text { There is no system for tracking } \\
\text { the CPD effectiveness of } \\
\text { teachers. }\end{array} \\
\end{array}$ & $\begin{array}{c}\text { Selection, systematization of tools for } \\
\text { studying the effectiveness of CPD courses }\end{array}$ \\
\hline Planning & $\begin{array}{l}\text { A formal approach to } \\
\text { developing an individual } \\
\text { teacher development plan. }\end{array}$ & $\begin{array}{l}\text { Development of reasoned plans for the } \\
\text { individual development of teachers, taking } \\
\text { into account the needs and capabilities of } \\
\text { each teacher. }\end{array}$ \\
\hline Projecting & $\begin{array}{c}\text { Shortcomings in monitoring } \\
\text { the conditions for professional } \\
\text { development of teachers. }\end{array}$ & $\begin{array}{l}\text { Improving conditions for professional } \\
\text { development of teachers. }\end{array}$ \\
\hline
\end{tabular}




\begin{tabular}{|c|c|c|}
\hline \multicolumn{3}{|c|}{ Resource management } \\
\hline $\begin{array}{l}\text { Financial } \\
\text { resources }\end{array}$ & $\begin{array}{l}\text { Lack of budgetary funds } \\
\text { allocated for professional } \\
\text { development of teachers. }\end{array}$ & Rising of extrabudgetary funds. \\
\hline \multirow[t]{2}{*}{ Human Resources } & \multirow{2}{*}{$\begin{array}{c}\text { Lack of differentiated forms of } \\
\text { work with different categories } \\
\text { of teachers. }\end{array}$} & $\begin{array}{l}\text { Planning and organization of work with } \\
\text { different categories of teachers. }\end{array}$ \\
\hline & & $\begin{array}{l}\text { Planning and organization of work to prevent } \\
\text { the stagnation of experienced teachers }\end{array}$ \\
\hline \multirow[t]{2}{*}{ Informing } & $\begin{array}{l}\text { Late informing about the } \\
\text { timing of coursework for the } \\
\text { upcoming academic year. }\end{array}$ & $\begin{array}{c}\text { Informing teachers about courses as offers } \\
\text { are received. }\end{array}$ \\
\hline & $\begin{array}{l}\text { Lack of alternative forms of } \\
\text { teacher training and CPD. }\end{array}$ & $\begin{array}{l}\text { Search for alternative forms of education; } \\
\text { Distance learning platforms, web-sites } \\
\text { "Academy of Parental Education", } \\
\text { "September 1", etc. }\end{array}$ \\
\hline \multicolumn{3}{|l|}{ Activities } \\
\hline \multirow[t]{4}{*}{ Educational } & $\begin{array}{l}\text { The need for annual updating } \\
\text { of information on the topics of } \\
\text { self-education. }\end{array}$ & $\begin{array}{c}\text { Collection and systematization of } \\
\text { information on the topics of self-education. }\end{array}$ \\
\hline & $\begin{array}{c}\text { The need to implement the } \\
\text { work plan of the educational } \\
\text { institution for the academic } \\
\text { year. }\end{array}$ & $\begin{array}{l}\text { In-service training and CPD of teachers in } \\
\text { accordance with the objectives of the annual } \\
\text { work plan of the educational institution; } \\
\text { Analytical skills training. }\end{array}$ \\
\hline & $\begin{array}{l}\text { Insufficient level of } \\
\text { competence of teachers on } \\
\text { certification issues. }\end{array}$ & Planning of teachers' certification. \\
\hline & $\begin{array}{c}\text { Insufficient level of } \\
\text { competence of teachers on the } \\
\text { implementation of the Federal } \\
\text { State Educational Standard } \\
\text { into the structure and } \\
\text { conditions for the realization of }\end{array}$ & $\begin{array}{l}\text { Study of regulatory documents on the } \\
\text { implementation of Federal State Demands } \\
\text { into the structure and conditions of the } \\
\text { educational programs. } \\
\text { Continuing work on the implementation of } \\
\text { educational programs during the academic }\end{array}$ \\
\hline \multirow[t]{4}{*}{ Innovative } & $\begin{array}{c}\text { Low competence in ICT } \\
\text { technoloov }\end{array}$ & $\begin{array}{c}\text { Self-education; } \\
\text { ICT Training courses }\end{array}$ \\
\hline & $\begin{array}{c}\text { Insufficient level of project } \\
\text { skills }\end{array}$ & $\begin{array}{l}\text { Improving the level of professional skills in } \\
\text { the imnlementation of nroiect technologv }\end{array}$ \\
\hline & $\begin{array}{l}\text { Low level of competence in } \\
\text { teacher's portfolio technology. }\end{array}$ & $\begin{array}{c}\text { Training seminars, workshops, consultations, } \\
\text { coaching. }\end{array}$ \\
\hline & $\begin{array}{l}\text { Unwillingness to go through } \\
\text { the certification procedure } \\
\text { under the new form }\end{array}$ & Motivation. \\
\hline \multirow[t]{4}{*}{$\begin{array}{l}\text { Support and } \\
\text { guidance }\end{array}$} & $\begin{array}{c}\text { Using traditional forms of } \\
\text { methodical support to teaching } \\
\text { staff. }\end{array}$ & $\begin{array}{l}\text { Introduce innovative group and individual } \\
\text { forms of work into the practice of } \\
\text { methodological support and guidance, } \\
\text { special attention to active and interactive }\end{array}$ \\
\hline & $\begin{array}{l}\text { Inability of newly trained } \\
\text { teachers to determine the topic } \\
\text { of self-education. }\end{array}$ & $\begin{array}{l}\text { Creation of individual trajectories for the } \\
\text { development of newly trained teachers. }\end{array}$ \\
\hline & $\begin{array}{l}\text { Lack of differentiated forms of } \\
\text { work with different categories } \\
\text { of teachers. }\end{array}$ & $\begin{array}{l}\text { Updating the forms and methods of working } \\
\text { with teaching staff, taking into account a } \\
\text { differentiated abproach. }\end{array}$ \\
\hline & $\begin{array}{l}\text { Lack of tools for studying the } \\
\text { personal qualities of teachers. }\end{array}$ & $\begin{array}{l}\text { Creation of a bank of diagnostic tools for } \\
\text { studying the personal qualities of teachers. }\end{array}$ \\
\hline
\end{tabular}




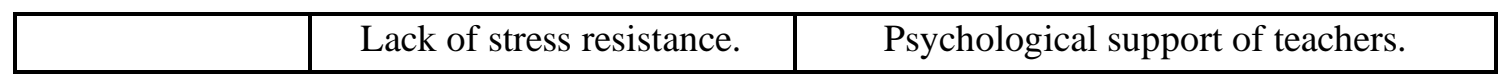

The sequence of actions to achieve a quality result could be as follows:

- to identify the basic steps and processes required to solve the problem;

- to determine their sequence and relationship;

- to identify effective criteria and methods;

- to provide the availability of resources and information necessary to support the implementation of processes and their monitoring;

- to observe, measure, analyze processes; improvement.

- to carry out activities necessary to achieve planned results and continuous

\section{Result Analysis}

Based on the process approach, we identified four stages of introducing the CPD Management Model of a teacher.

\section{Stage 1. Reflective and informational.}

Development and discussion of the model, study of experience on the problem of supporting the professional growth of teachers in the inter-certification period.

Analysis by teachers of their professional capabilities, difficulties and potentialities.

\section{Stage 2. Organizational.}

Systematization of observation data and analysis of pedagogical innovative activities, participation of teachers in methodological work.

We believe that for a successful constructive way out of the professional development crisis, an important role should be played by individual and group forms of psychological counseling. The counseling should be provided as part of the implementation of the model and can be classified as follows:

- informational, when the teacher is presented with the necessary information that contributes to the improvement of his/her professional activity;

- instructive, when special instructions are given for the teacher, i.e. recommendations to solve particular professional and personal problems; are developed;

- formative, when innovative strategies for the development of an educational institution

- psychological (preventive), aimed at creating a favorable psychological climate in the team, at preventing conflicts, effective interpersonal communication.

\section{$\underline{\text { Stage 3. Practical }}$}

Development of an action plan aimed at: 
- improving the monitoring system of pedagogical activity;

- updating the forms and methods of methodological work with teachers, forms of advanced training;

- mastering new forms of attestation of teaching and administrative staff;

- planning the continuous professional development of teachers;

- increasing the innovative potential of teaching staff.

$\underline{\text { Stage 4. Generalizing and analytical }}$

At this stage, the results of professional development are presented: the publication of articles, presentation at the competition of pedagogical skills, discussion of the results at the level of the educational institution, district, professional learning community.

3.

The main stages of the CPD Management Model implementation are described in Table

(Table 3): Stages of implementation of the CPD Management Model of educational psychologists

\begin{tabular}{|c|c|c|}
\hline \multicolumn{3}{|l|}{ Stage 1. Reflecti } \\
\hline Activity content & Results achieved & $\begin{array}{l}\text { the CPD Management Model } \\
\text { outcomes }\end{array}$ \\
\hline \multicolumn{3}{|c|}{$\begin{array}{l}\text { Information work with teachers Teachers were informed aboutProfessional development plans } \\
\text { on the introduction of athe content and timing of thefor 2020-2023. } \\
\text { professional standard, newimplementation of a } \\
\text { forms of certification.professional standard, a new } \\
\text { Reflecting on the current levelform of certification. } \\
\text { of development of teachers, } \\
\text { identifying growth points and a } \\
\text { trajectory for further } \\
\text { develonment } \\
\text { Stage } 2 \text { Organizational }\end{array}$} \\
\hline \multicolumn{3}{|c|}{ 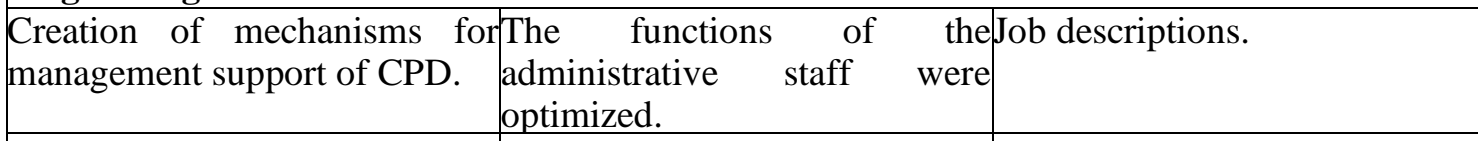 } \\
\hline \multicolumn{3}{|c|}{ 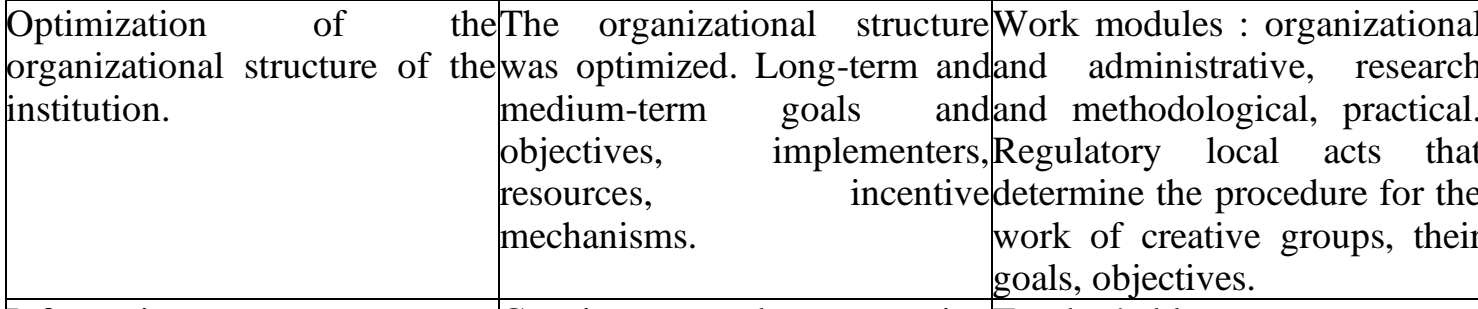 } \\
\hline Information supp & $\begin{array}{l}\text { Creating and } \\
\text { individual teacher }\end{array}$ & \\
\hline \multicolumn{3}{|c|}{$\begin{array}{l}\text { Analysis of the material andThe directions of developmentPerspective plan for } \\
\text { technical resources available in of material and technicalmodernization of the material } \\
\text { the institution to increaseresources and infrastructureand technical resources and } \\
\text { professional competence of have been determined. } \\
\text { teachers. }\end{array}$} \\
\hline
\end{tabular}




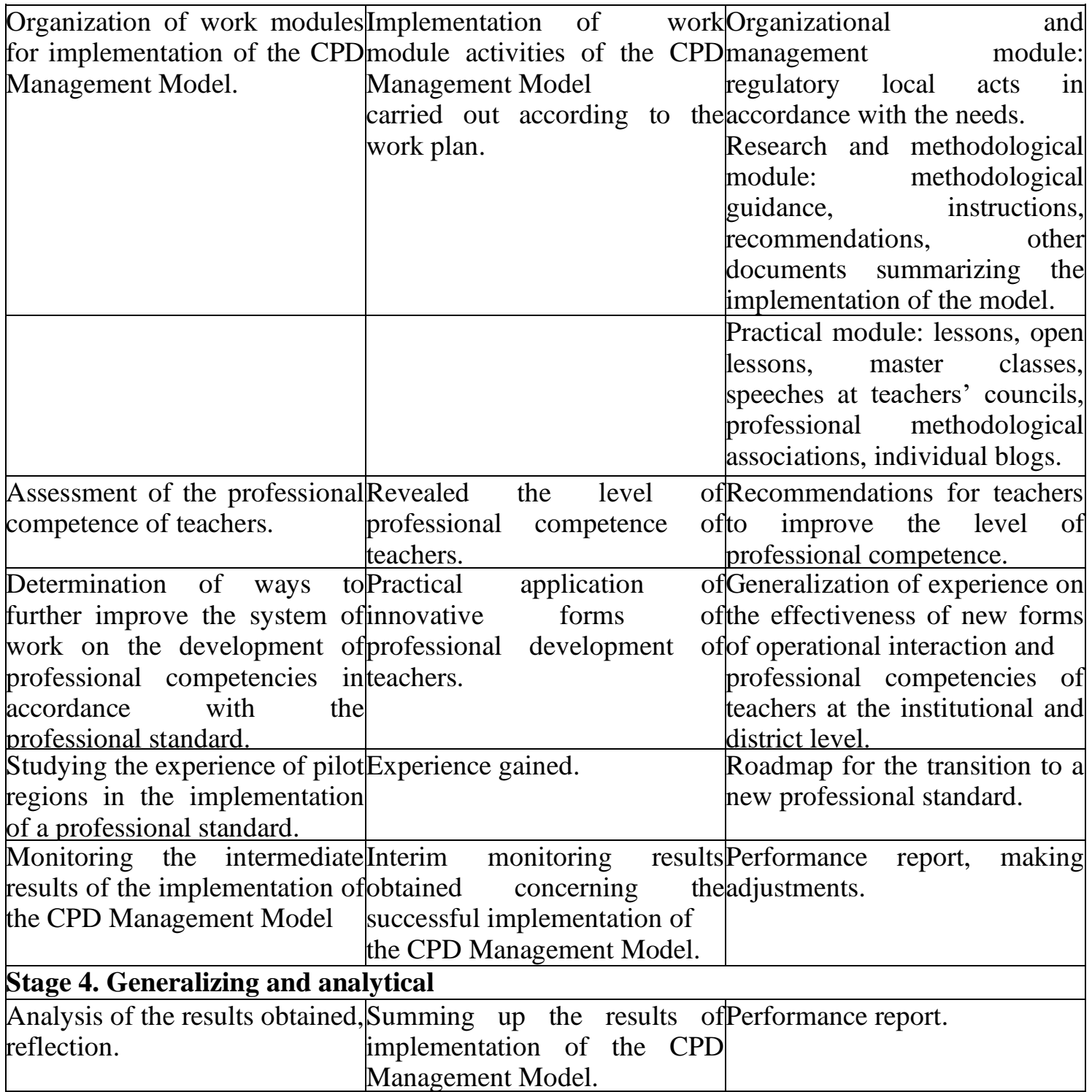

\section{Conclusion}

To develop the psychological and pedagogical competencies of teachers, the following methods can be recommended:

- communicative and psychological trainings in order to improve the professional position of a teacher, develop mental processes (pedagogical thinking, reflection and other personal traits), improve skills for psychological and emotional decompression, expand professional knowledge;

- analysis of specific pedagogical situations in order to jointly solve common professional problems (low academic performance of students, conflict situations in the classroom, with colleagues, etc.);

- tasks related to the development of teacher's skills to evaluate and improve the individual style, perspective career positions and attitudes in order to motivate self-education;

- tasks related to the development of professionally important personal characteristics (analysis and reflection of the teacher's pedagogical activity, methods of synectics (problemsolving method of creative brainstorming), methods of discussion, etc. 
We recommend the following possible forms used to improve pedagogical competence:

- theoretical and practical conferences and seminars at various levels;

- open lessons, master classes, workshops;

- project and research activities of teachers;

- mentoring, coaching;

- professional self-education;

- trainings, discussions, refresher/upgrade courses, etc.

\section{Referencias}

Abramova, G.S. (1994). Introduction to practical psychology: textbook. Moscow: Mezhdunar. ped. academy.

Bermus, A.G. (2020). Practical pedagogy: tutorial. Moscow: Yurayt Publishing House.

Bírová, J., Kružlík, P., Kalimullin, A., Sokolova, N., Haroun, Z., Králik, R., Vasbieva, D. (2018). Mathematical and Statistical Bibliometric Indicators for Scholars in the Field of Romance Languages and Linguistics. EURASIA: Journal of Mathematics, Science and Technology Education, 14(12).

Blinov, V.I. (2019). Methods of vocational training: a textbook for secondary vocational education. Moscow: Yurayt Publishing House.

Blinova, S., Dugina, T., Zabolotskikh, A. (2018). Teaching mixed nationality groups (on the example of students from the Northern Caucasus region). INTED2018: Proceedings of the 12th International Technology, Education and Development Conference (pp. 79777982). Valencia.

Burina, E.V. (2015). The concept of an artificial language environment for teaching a second foreign language (on the example of the French language) Bulletin of the RUDN University. Series "Russian and foreign languages and methods of teaching", 3, 59-65.

Dolzhich, E., Dmitrichenkova, S. (2018). Computer science terminology (a case study of the Spanish language). INTED2018: Proceedings of the 12th International Technology, Education and Development Conference (pp. 2556-2559). Valencia.

Gorev, P., Telegina, N., Karavanova, L., Feshina, S. (2018). Puzzles as a didactic tool for development of mathematical abilities of junior schoolchildren in basic and additional mathematical education. EURASIA: Journal of Mathematics, Science and Technology Education, 14(10), 178-185.

Gurevich, P.S. (2019). Psychology and pedagogy. Textbook and workbook for academic bachelor's degree. Moscow: Yurayt Publishing House.

Isaeva, N.I. (2002). Development of the professional culture of an educational psychologist: dis. ... doct. psychol. sciences. Belgorod.

Neverkovich, S., Bubnova, I., Kosarenko, N., Sakhieva, R., Sizova, Zh., Zakharova, V., Sergeeva, M. (2018). Students' internet addiction: study and prevention. Eurasia Journal of Mathematics, Science and Technology Education, 14(4), 1483-1495.

Ovcharova, R.V. (2003). Practical psychology of education: a textbook for students of psychol. fac. of universities. Moscow: Publishing house "Academy".

Patrusheva, I.V. (2019). Psychology and pedagogy of the game. Textbook for secondary vocational education. Moscow: Yurayt Publishing House.

Romanova, E.S. (1992). Psychology of professional development of personality: author. ... doct. psychol. sciences. Moscow.

Sergeeva, M., Shumeyko, A., Serebrennikova, A., Denisov, A., Bondarenko, N., Getmanova, E. (2018). Innovative pedagogical experience in practice of modern education modernization. Modern Journal of Language Teaching Methods, 8(11), 814-823. 
Sharonova, S., Trubnikova, N., Sokolova, N. (2018). Interpreting religious symbols as basic component of social value formation. European Journal of Science and Theology, 14(3), 117-129.

Utemov, V., Khusainova, R., Sergeeva, M., Shestak, V. (2018). Full Packaged Learning Solutions for Studying Mathematics at School. Eurasia Journal of Mathematics, Science and Technology Education, 14(12).

Volkova, Y., Panchenko, N. (2018). Discourse variation of the concepts of destructive emotions. Vestnik Rossiiskogo Universiteta Druzhby Narodov. Russian journal of linguistics, 22(1), 175-194.

Wang, S., Gorbunova, N., Masalimova, A., Bírová, J., Sergeeva, M. (2018). Formation of academic mobility of future foreign language teachers by means of media education technologies. Eurasia Journal of Mathematics, Science and Technology Education, 14(3), 959-976.

Zeer, E.F. (2003). Psychology of Professions: Textbook for University Students. Moscow: Academic Project. 